\title{
Prostaglandins are not mediators of the intestinal response to cholera toxin
}

\author{
G S SMITH, G. WARHURST, A TONGE, AND L A TURNBERG \\ From the Department of Medicine, Hope Hospital, University of Manchester School of Medicine, Salford
}

\begin{abstract}
SUMmARY We have determined the release of prostaglandin $E_{2}$ into the lumen of closed ileal loops in the rat and have measured the capacity of the mucosa to synthesise and degrade prostaglandin $E_{2}$ both in control animals and after exposure to cholera toxin or bisacodyl. Exposure to cholera toxin caused no change in any of these measurements whereas bisacodyl caused an increase in the luminal $\mathrm{PGE}_{2}$ content. We conclude that the secretion stimulated by cholera toxin is not mediated by locally produced prostaglandins.
\end{abstract}

The possibility that cholera toxin may stimulate intestinal secretion by activating local production of prostaglandins has been raised by the observation that non-steroidal anti-inflammatory drugs which inhibit prostaglandin production inhibit cholera toxin induced secretion. ${ }^{12}$ These anti-inflammatory drugs, however, fail to inhibit the stimulation of adenylate cyclase by cholera toxin at concentrations sufficient to inhibit prostaglandin synthesis. ${ }^{3}$ Furthermore, aspirin and indomethacin enhance absorption in non-stimulated rabbit ileal mucosa, ${ }^{4}$ suggesting that these drugs influence ion transport without necessarily inhibiting prostaglandin synthetic activity. Thus the role of prostaglandins in mediating secretory diarrhoea associated with cholera toxin remains uncertain. We have examined this question further by determining the synthesis and degradation of prostaglandin $\mathrm{E}_{2}\left(\mathrm{PGE}_{2}\right)$ in rat intestinal mucosal homogenates under basal conditions and after stimulation with cholera toxin. We have also determined the $\mathrm{PGE}_{2}$ content of luminal fluid after exposure of loops of intestine to cholera toxin and to the laxative drug bisacodyl, which is believed to act by liberating local prostaglandins.

\section{Methods}

ANIMALS

Male Sprague-Dawley rats, weighing 200-250 g were anaesthetised with sodium pentobarbital $(65$ $\mathrm{mg} / \mathrm{kg}$ subcutaneously) after a 24 hour fast. A $20 \mathrm{~cm}$

Address for correspondence: Professor L A Turnberg. Department of Medicine, Hope Hospital, University of Manchester School of Medicine. Eccles Old Road, Salford M6 8HD.

Received for publication 24 August 1984 segment of ileum, $5 \mathrm{~cm}$ proximal to the ileocaecal junction was cannulated and flushed with $20 \mathrm{ml}$ of warm saline. The segment was then filled, but not distended, with approximately $2.5 \mathrm{ml}$ of a solution containing $\mathrm{NaCl} 140 \mathrm{mM}$, sodium hydrogen phosphate $5 \mathrm{mM}, \mathrm{pH} \mathrm{7.4}$. The volume inserted was accurately measured by filling the loops from a syringe which was weighed before and after the loops had been filled. In control loops, only the phosphate/saline solution was inserted while in other loops either cholera toxin, $5 \mu \mathrm{g} / \mathrm{ml}$, or bisacodyl $100 \mu \mathrm{g} / \mathrm{ml}$ was included. After intestinal loops had been filled they were returned to the abdominal cavity, which was covered with a damp gauze to prevent desiccation during the subsequent incubation period. The body temperature was monitored continuously and maintained at $35^{\circ} \mathrm{C}$ with a heating lamp.

In the cholera toxin experiments, after a two-hour incubation period the fluid in the toxin exposed and control loops was drained off and in each instance replaced by phosphate/saline solution for measurement of absorption or secretion. An accurately measured volume of fluid was inserted and after 30 minutes the loops were removed and weighed. The fluid was then drained off and retained for $\mathrm{PGE}_{2}$ determination. The empty segment of intestine was reweighed and the volume of fluid that had been absorbed was calculated.

In the bisacodyl experiments, incubations were continued in both control and bisacodyl-containing loops for one hour, the fluid was removed and retained for $\mathrm{PGE}_{2}$ analysis and the extent of absorption or secretion determined as described above. 
PGE 2 DETERMINATION IN LOOP FLUIDS

A $1 \mathrm{ml}$ sample of the fluid was acidified to $\mathrm{pH} 3$ with $2 \mathrm{M}$ citric acid and $50 \mu \mathrm{l}$ of ${ }^{3} \mathrm{H} \mathrm{PGE}_{2}(60000 \mathrm{dpm})$ added as recovery marker. The fluid was then extracted into ether and the ether layer removed and reduced to dryness under nitrogen. The dried sample was resuspended in $500 \mu$ l radioimmunoassay buffer and $100 \mu \mathrm{l}$ was taken to assess recovery of $\mathrm{PGE}_{2}$. A further $100 \mu \mathrm{l}$ was used for determination of $\mathrm{PGE}_{2}$ content by radioimmunoassay (see below).

ASSAY FOR PGE 2 SYNTHESIS AND DEGRADATION The techniques for these determinations have been described previously, ${ }^{5}$ but briefly the mucosa of the loop of intestine under investigation was cut along its length and removed by scraping with a microscope slide. The mucosal scrapings (100-200 mg wet weight) were homogenised in a buffer containing potassium phosphate $100 \mathrm{mmol}$, EDTA $20 \mathrm{mmol}$, $\mathrm{pH} 7 \cdot 4$, at $4^{\circ} \mathrm{C}$ and filtered through a nylon mesh. Aliquots of homogenate were then assayed for their synthetic and degradative capacity.

\section{SYNTHESIS}

Determinations were carried out by incubating approximately $1 \mathrm{mg}$ protein for $2 \mathrm{~min}$ at $37^{\circ} \mathrm{C}$ in $1 \mathrm{ml}$ of phosphate/EDTA buffer containing $0.8 \mathrm{mM}$ arachidonic acid, $0.06 \mathrm{mM}$ noradrenaline, $2 \mathrm{mM}$ glutathione, $0.04 \mathrm{mM}$ hydroquinone, plus $60 \mu \mathrm{g} / \mathrm{ml}$ haemoglobin and approximately $75000 \mathrm{dpm}$ $\left[{ }^{3} \mathrm{H}\right] \mathrm{PGE}_{2}$ as a recovery marker.

\section{DEGRADATION}

Determinations were carried out by incubating approximately $1 \mathrm{mg}$ protein for $5 \mathrm{~min}$ at $37^{\circ} \mathrm{C}$ in $1 \mathrm{ml}$ of phosphate/EDTA buffer containing $2.5 \mathrm{mM}$ $\mathrm{NAD}^{+}, 5 \mu \mathrm{M} \mathrm{PGE}$, and $0.18 \mu \mathrm{Ci}$ of $\left[{ }^{3} \mathrm{H}\right] \mathrm{PGE}_{2}$.

Both the synthesis and degradation assays were stopped by the addition of $100 \mu$ l of $2 \mathrm{M}$ citric acid to reduce the $\mathrm{pH}$ to 3 followed by extraction with $3 \mathrm{ml}$ diethyl ether. Blanks were prepared in which acid was added before the homogenate. For each assay $200 \mu \mathrm{l}$ of the diethyl ether phase was placed onto the preadsorbent area of Whatman Linear K TLC plates (LK6D), dried and the plates developed in the organic phase of ethyl acetate/iso-octane/acetic acid/ water (110:50:20:100). For the degradation assay the region corresponding to the degradation product 13,14-dihydro-15-ketoPGE ${ }_{2}$ was scraped off and counted in PCS scintillant. For the synthesis assay the region corresponding to $\mathrm{PGE}_{2}$ was scraped off and eluted into $1 \mathrm{ml}$ of radioimmunoassay buffer $\left(100 \mathrm{mM} \mathrm{KH}_{2} \mathrm{PO}_{4}, 155 \mathrm{mM} \mathrm{NaCl}, 15 \mathrm{mM} \mathrm{NaN}_{3}\right.$ plus $0.1 \%$ gelatin, $\mathrm{pH} 7 \cdot 4$ ) and assayed for $\mathrm{PGE}_{2}$ using commercially available antisera (Pasteur Institute).
All biochemicals were obtained from the Sigma Chemical Co Ltd, 5,6,8,11,12,14,15(n) ${ }^{3} \mathrm{H} \mathrm{PGE}_{2}$ and PCS scintillant were obtained from the Radiochemical Centre, Amersham. $\mathrm{PGE}_{2}$ antisera were obtained from Institut Pasteur, Paris. Bisacodyl was a gift from Boehringer-Ingleheim.

\section{Results}

Cholera toxin inhibited net absorption during the 30 minutes after exposure to the toxin: Control absorption $0.63 \pm 0.133 \mathrm{ml} / \mathrm{g} / \mathrm{h} \quad(\mathrm{n}=4)$; Cholera toxin $0 \cdot 019 \pm 0.04 \mathrm{ml} / \mathrm{g} / \mathrm{h}(\mathrm{n}=7)$.

Measurement of $\mathrm{PGE}_{2}$ synthetic and degradative capacity in scrapings of intestinal mucosa taken from control and cholera toxin-exposed loops of intestine revealed that the toxin had no effect on either of these activities (Table 1). In addition, the $\mathrm{PGE}_{2}$ content of luminal fluid was similar in control and toxin-exposed loops (Table 1).

Bisacodyl $(100 \mu \mathrm{g} / \mathrm{ml})$ reduced absorption from $0.81 \pm 0.14 \mathrm{ml} / \mathrm{g} / \mathrm{h} \quad(\mathrm{n}=7)$ to $0.06 \pm 0.075 \mathrm{ml} / \mathrm{g} / \mathrm{h}$ $(\mathrm{n}=8)$, in control and bisacodyl loops respectively. In this instance, however, bisacodyl caused a significant increase in $\mathrm{PGE}_{2}$ content of luminal fluid. $\mathrm{PGE}_{2}$ synthesis and degradation rates were both reduced but not to a statistically significant extent (Table 2).

\section{Discussion}

Considerable evidence has accumulated to indicate that cholera toxin induces intestinal secretion by activation of epithelial adenylate cyclase, ${ }^{6}$ followed by an increase in intracellular cyclic AMP. ${ }^{7}$ In a number of isolated cell systems the toxin has been shown to bind to a specific ganglioside (GM1), ${ }^{8}$ followed by the penetration of the cell membrane by the A subunit of the toxin. ${ }^{9}$ This subunit irreversibly activates the plasma membrane adenylate cyclase by promoting the ADP ribosylation of the GTP regulatory subunit. ${ }^{10}$

Prostaglandin $\mathrm{E}_{2}$ also stimulates intestinal secretion by activation of epithelial adenylate cyclase, ${ }^{6}$

Table 1 Effect of cholera toxin on mucosal $P G E_{2}$ synthesis and degradation and luminal $P G E_{2}$ content

\begin{tabular}{lll}
\hline $\begin{array}{l}P G E_{2} \text { synthesis } \\
\text { (pmollmg } \\
\text { protein/min) }\end{array}$ & $\begin{array}{l}P G E_{2} \text { degradation } \\
\text { (pmol/mg } \\
\text { protein/min) }\end{array}$ & $\begin{array}{l}\text { Luminal } P G E_{2} \\
\text { content }(p m o l / g \\
\text { loop tissue) }\end{array}$ \\
\hline Control 16.8 $\pm 3 \cdot 8(4)$ & $462 \pm 106(4)$ & $1 \cdot 61 \pm 0 \cdot 34(4)$ \\
Cholera 13.04 $\pm 2 \cdot 8(7)$ & $389 \pm 90(8)$ & $1 \cdot 32 \pm 0 \cdot 2(7)$ \\
\hline
\end{tabular}

Mean \pm 1 SEM, numbers in parentheses $=$ no of studies. 
Table 2 Effect of bisacodyl on mucosal $P G E_{2}$ synthesis and degradation and luminal $P G E_{2}$ content

\begin{tabular}{lll}
\hline $\begin{array}{c}\text { GE synthesis } \\
\text { (pmollmg } \\
\text { protein/min) }\end{array}$ & $\begin{array}{l}P G E_{2} \text { degradation } \\
\text { (pmol/mg } \\
\text { protein/min) }\end{array}$ & $\begin{array}{l}\text { Luminal } P G E_{2} \\
\text { content }(p m o l / g \\
\text { loop tissue) }\end{array}$ \\
\hline Control $14 \cdot 1 \pm 2 \cdot 8(7)$ & $359 \pm 85(7)$ & $1 \cdot 48 \pm 0 \cdot 23(7)$ \\
Bisacodyl $8 \cdot 67 \pm 1 \cdot 51(7)$ & $205 \pm 45(8)$ & $3 \cdot 14 \pm 0 \cdot 7(8)^{*}$ \\
\hline
\end{tabular}

Mean \pm SEM, ${ }^{*} \mathrm{p}<0 \cdot 05$, numbers in parentheses $=$ no of studies.

possibly by binding to a prostaglandin receptor. In contrast to cholera toxin activation, however, prostaglandin activation of adenylate cyclase is reversible. Nevertheless similarities in action between prostaglandin and cholera toxin-induced secretion prompted the proposal that the toxin may act by releasing local prostaglandins. ${ }^{11}$ The subsequent demonstration ${ }^{12}$ that prostaglandin synthesis inhibitors, such as aspirin and indomethacin, reduced the secretion caused by cholera toxin seemed to support this proposal. A more direct action on ion transport, than one involving inhibition of prostaglandin synthesis is suggested by the observation that these drugs enhance absorption in the basal state. $^{4}$

In view of these conflicting observations we investigated further the possible involvement of prostaglandins in the action of cholera toxin in the intestine by measuring the capacity of the mucosa to synthesise and degrade $\mathrm{PGE}_{2}$, and by measuring release of $\mathrm{PGE}_{2}$ into the lumen after cholera toxin exposure. The results indicate that the toxin does not influence either prostaglandin synthetic or degrading enzyme activity, nor is $\mathrm{PGE}_{2}$ released in increased amounts into luminal fluid. Similar results on the luminal levels of $\mathrm{PGE}_{2}$ after exposure to pure cholera toxin have also been reported for rabbit ileum. ${ }^{12}$

As it has been suggested that bisacodyl-induced secretion is mediated by local prostaglandin release, ${ }^{13}$ we used this drug as a positive control. Although bisacodyl failed to influence the enzymes concerned with prostaglandin synthesis or degradation, it did significantly increase prostaglandin release into the luminal fluid as had been previously demonstrated. It is possible that increased release of $\mathrm{PGE}_{2}$ is the result of greater availability of arachidonate, the precursor for $\mathrm{PGE}_{2}$ synthesis. The enzyme concerned with availability of arachidonate is phospholipase A2 and it is possible that increased activity of this enzyme is responsible for the increased $\mathrm{PGE}_{2}$ release.

The results of these studies suggest that cholera toxin-induced secretion is not mediated by topical prostaglandin production in the mucosa.

We are grateful to the North Western Regional Health Authority for a grant to support this work.

\section{References}

1 Jacoby HI, Marshall $\mathrm{CH}$. Antagonism of cholera enterotoxin by anti-inflammatory agents in the rat. Naiure 1972; 235: 163-5.

2 Finck AD, Katz RL. Prevention of cholera induced intestinal secretion in the cat by aspirin. Nature 1972; 238: $273-4$

3 Powell DW, Farris RK. Effect of aspirin on cholera toxin stimulated intestinal electrolyte transport. Gastroenterology 1975; 68: 968.

4 Farris RK, Tapper EJ, Powell DW, Morris SM. Effect of aspirin on normal and cholera toxin stimulated intestinal electrolyte transport. J Clin Invest 1976; 57: 916-24.

5 Smith GS, Warhurst G, Turnberg LA. Synthesis and degradation of $\mathrm{PGE}_{2}$ in the epithelial and subepithelial layers of the rat intestine. Biochim Biophys Acta 1982; 713: $684-7$

6 Kimberg DV, Field M, Johnson J, Henderson A, Gershon E. Stimulation of intestinal mucosal adenylate cyclase by cholera enterotoxin and prostaglandins. $J$ Clin Invest 1971; 50: 1218-30.

7 Kimberg DV, Field M, Gershon E, Henderson A. Effects of prostaglandin and cholera toxin on intestinal mucosal cAMP accumulation. J Clin Invest 1974; 53: 941-9.

8 Cuatrecasas P. Interaction of vibrio cholerae enterotoxin with cell membranes. Biochemistry 1973; 12: 3547-58.

9 Field M. Mechanisms of action of cholera and E. Coli enterotoxins. Am J Clin Nutr 1979; 32: 189-96.

10 Enomoto K, Gill DM. Cholera toxin activation of adenyl cyclase. J Biol Chem 1980; 255: 1252-8.

11 Bennet A. Cholera and prostaglandins. Nature 1971; 231: 536 .

12 Bedwani JR, Okpako DT. Effects of crude and pure cholera toxin on prostaglandin release from rabbit ileum. Prostaglandins 1975; 10: 117-27.

13 Beubler E, Juan H. Prostaglandin E mediated laxative effect of diphenolic laxatives. Naunyn-Schmiedebergs Arch Pharmacol 1978; 205: 241-6. 